\title{
Seasonal and vertical patterns of egg-laying by the freshwater fish louse Argulus foliaceus (Crustacea: Branchiura)
}

\author{
A. J. Harrison ${ }^{1}$, N. F. S. Gault ${ }^{2,3, *}$, J. T. A. Dick ${ }^{1}$ \\ ${ }^{1}$ School of Biological Sciences, Queen's University Belfast, 97 Lisburn Road, Belfast BT9 7BL, UK \\ ${ }^{2}$ School of Agriculture and Food Science, Queen's University Belfast and ${ }^{3}$ Food Science Division, Department of Agriculture \\ and Rural Development, Newforge Lane, Belfast BT9 5PX, UK
}

\begin{abstract}
Argulus foliaceus is a damaging fish ectoparasite for which new control measures are being developed based on egg-removal. In an attempt to develop further understanding of seasonal and vertical egg-laying patterns in this parasite, egg-laying activity was monitored over the period 14 April to 17 November 2003 in 2 rainbow trout Oncorhynchus mykiss fisheries in Northern Ireland, UK. At Site 1, egg-laying was continuous from 21 April to 17 November, when water temperature was above 8 to $10^{\circ} \mathrm{C}$. At Site 2, egg-laying was continuous from 4 June to 29 October. In the early months of the season, egg-laying was recorded mainly within the top $1 \mathrm{~m}$ of the water column; however, a significant shift to deep water egg-laying was recorded between 7 July and 17 November at Site 1 and between 20 August and 29 October at Site 2. Egg clutches were preferentially laid at depths of up to $8.5 \mathrm{~m}$ during this time (Site 2), a feature of egg-laying hitherto unappreciated. Temperature and dissolved oxygen did not differ significantly among depths, but there was an increase in water clarity over time. However, the precise environmental triggers for deep water egg-laying are still unclear. These new insights into the reproductive behaviour of this species will be useful in developing control methods based on egg-removal.
\end{abstract}

KEY WORDS: Argulus foliaceus $\cdot$ Freshwater fish louse $\cdot$ Egg-laying $\cdot$ Vertical distribution $\cdot$ Depth Parasite $\cdot$ Rainbow trout

\section{INTRODUCTION}

Argulus foliaceus is an obligate branchiuran fish ectoparasite that infects many freshwater fishes in the British Isles (Holland \& Kennedy 1997). It feeds by piercing the skin of the host, with heavy infestations leading to serious skin damage, stress and death (Kabata 1970). In recent years, A. foliaceus has become a major pest of UK sport fisheries, with fish stress and mortalities having serious impacts in Scotland (Northcott et al. 1997) and Northern Ireland (Gault et al. 2002). Gault et al. (2002) developed a novel control method using plastic egg-laying boards, however; their effectiveness relies on knowledge of egg-laying patterns. Herein, we examine egg-laying with respect to seasonality and water depth.

\footnotetext{
*Corresponding author. Email: norman.gault@dardni.gov.uk
}

Following copulation on the host fish, female Argulus foliaceus must leave the host in order to lay their eggs on a suitable solid substrate (Pasternak et al. 2000). Females have been observed under laboratory conditions to lay 2 to 4 egg clutches, and then return to a host before detaching again to repeat the process within 2 to $4 \mathrm{~d}$ (Pasternak et al. 2000). Eggs are laid in strings or clutches, each containing 4 to 250 eggs (Bauer 1959, Rahman 1995), with an average of 100 to 150 eggs (Bower-Shore 1940). In a natural environment, egg clutches are deposited on most readily available hard substrata (Hoffman 1977). Bauer (1959) observed that clutches are mainly laid in shady areas and within the top $1 \mathrm{~m}$ of the water column, but gave no indication as to the maximum depth of water available in his investigation: it could be the case that the

C Inter-Research 2006 • www.int-res.com 
maximum egg-laying depth recorded was simply a reflection of the maximum water depth available in fish ponds. The concept of $A$. foliaceus being regarded as a shallow water species has since been perpetuated in the literature (Hoffman 1977, Mikheev et al. 2001, 2003, Hakalahti et al. 2004). However, until now, no thorough investigation on the egg-laying depth of this species has been conducted. In their work with novel egg-laying boards deployed in a stillwater rainbow trout fishery in Northern Ireland, Gault et al. (2002) found egg clutches laid at depths of up to $2 \mathrm{~m}$, but did not assess egg-laying in deeper regions.

The main aims of this study were to (1) elucidate any seasonal patterns in egg-laying activity and the depth at which egg-laying occurs, and (2) examine egglaying patterns with respect to seasonal variations in water temperature, dissolved oxygen content and Secchi depth.

\section{MATERIALS AND METHODS}

Study sites. Site 1: This is a 12.9 ha rainbow trout Oncorhynchus mykiss fishery located near Bangor, County Down, N. Ireland $\left(54^{\circ} 37^{\prime} \mathrm{N}, 5^{\circ} 45^{\prime} \mathrm{W}\right)$. It is the lower of 2 reservoirs, separated by approximately $700 \mathrm{~m}$ from the upper reservoir. Both reservoirs are owned by the Department of the Environment for Northern Ireland, and are leased by Bangor Angling Club for the purposes of sport fishing. Rainbow trout are stocked annually. A water extraction tower is used to remove water for municipal supplies. The site is moderately eutrophic, with a maximum depth of $7.2 \mathrm{~m}$ and has a resident population of 3-spined sticklebacks Gasterosteus aculeatus. The fishery had epizootics of Argulus foliaceus resulting in massive fish kills in 1995, 1999 and 2002 (N. F. S. Gault pers. obs.).

Site 2: This is a 28 ha mixed (rainbow trout, pike Esox lucius, perch Perca fluviatilis, rudd Scardinius erythrophthalmus) fishery located near Portaferry, County Down $\left(54^{\circ} 24^{\prime} \mathrm{N}, 05^{\circ} 33^{\prime} \mathrm{W}\right)$ with good water clarity (Secchi depth down to $3.5 \mathrm{~m}$ ) and a maximum depth of $12 \mathrm{~m}$. It is used for commercial sport fishing, and is regularly stocked with rainbow trout. The majority of the bank side in this natural lake is covered with dense rushes, and hence most fishing is conducted from boats. There is also a substantial growth of water lilies during the summer months. A water extraction tower on one side of the lake is used by the Department of the Environment for Northern Ireland to remove water for municipal water supplies.

Sampling. Eggs of Argulus foliaceus were collected on $30 \times 30 \mathrm{~cm}$ corrugated polypropylene boards (see Gault et al. 2002). Each 'board string' consisted of 5 boards suspended from an anchored rope.
Site 1: We positioned 7 board strings 10 to $20 \mathrm{~m}$ from the bank along 2 sides of the reservoir, with the boards at depths of 0,1,2 and $3 \mathrm{~m}$ (rope) and $5.5 \mathrm{~m}$ (anchor). The first board strings were set on 7 April 2003, and were removed and replaced weekly until 17 November 2003. On each occasion, temperature and dissolved oxygen (Jenway 9150 meter) were taken at each depth for Board Strings 4, 5 and 6. Secchi depth was measured at each board string.

Site 2: We positioned 5 board strings in the centre of the lake, with the boards at depths of $0,2,4$ and $6 \mathrm{~m}$ (rope) and $8.5 \mathrm{~m}$ (anchor). The first board strings were set on 21 May 2003, and were removed and replaced weekly until 5 November 2003. Secchi depth was measured at each board string.

In the laboratory we recorded egg-laying activity for each board as (1) number of egg clutches, (2) average clutch length and (3) average egg length. The average egg length per board was calculated from 15 eggs: 5 eggs each from 1 large $(>2 \mathrm{~cm}), 1$ medium $(1$ to $2 \mathrm{~cm})$ and 1 small $(<1 \mathrm{~cm})$ clutch. Egg clutches were easily identified, as eggs were laid in rows and distinctly different from any other crustacean eggs or organic material on the boards. Argulus foliaceus was the only species of fish louse present at either study site.

Analyses. Site 1: The egg-laying season (30 wk) was divided into 5 equal time $(\mathrm{T})$ periods for the purpose of clarity of data analysis and presentation: T1 (14 April to 26 May), T2 (26 May to 7 July), T3 (7 July to 18 August), T4 (18 August to 29 September), T5 (29 September to 17 November). Temperature, dissolved oxygen (T1 to T4 only-meter failure during T5) and number of egg clutches (no. of clutches $\mathrm{d}^{-1}$ ) were examined in separate 2-factor ANOVAs with respect to depth and time (repeated measure). For boards that had no egg clutches, we obviously could not generate data on average clutch length or average egg length, and thus could not run 2-factor ANOVAs on these data sets. However, we collapsed the data by depth and examined the time effect in a 1-factor ANOVA and then collapsed the data by time to examine the depth effect. We used Fisher's least-significant-difference (FLSD) posthoc test (Sokal \& Rohlf 1995) for pairwise comparisons of means. We correlated Secchi depth (averages across board strings for each week) with time (all weeks).

Site 2: The egg-laying season (18 wk) was divided into 2 equal time periods: T1 (25 June to 20 August) and T2 (20 August to 29 October). The number of egg clutches was analysed as for Site 1. Mean clutch and egg length data were collapsed as for Site 1 and examined with Student's $t$-tests and 1-factor ANOVA. Secchi depth was analysed as for Site 1. 


\section{RESULTS}

\section{Site 1}

There was no significant difference in temperature among depths $\left(F_{4,32}=1.9\right.$, not significant; Fig. 1a), but temperature clearly followed a seasonal pattern $\left(F_{4,32}\right.$ =9.0, p < 0.0001; Fig. 1a). Whilst statistically significant $\left(F_{4,24}=7.8, \mathrm{p}<0.01\right)$, dissolved oxygen levels did not differ greatly among depths (Fig. 1b). Dissolved oxygen did, however, decline significantly over time $\left(F_{3,24}=492.2, \mathrm{p}<0.0001 ;\right.$ Fig. $\left.1 \mathrm{~b}\right)$ and there was a weak but significant interaction effect $\left(F_{12,24}=3.0, \mathrm{p}<\right.$
0.05). At $\mathrm{T} 1$, there was a slight increase in dissolved oxygen as depth increased, this reversed at T2, before becoming evident again during T3 to T4. Egg clutches were first observed on 21 April, the water temperature having reached $10^{\circ} \mathrm{C}$ the previous week. Egglaying was continuous throughout the season until 17 November, when the water temperature fell below $8^{\circ} \mathrm{C}$. Mean number of egg clutches differed among depths $\left(F_{4,96}=39.4, \mathrm{p}<0.0001\right.$; Fig. 2a) and over time $\left(F_{4,96}=11.7, \mathrm{p}<0.0001\right)$, with a significant interaction effect $\left(F_{16,96}=11.8, \mathrm{p}<0.0001\right)$. Clearly, Fig. 2a shows that egg-laying activity increased dramatically by T3, with a reversal from predominantly shallow water to
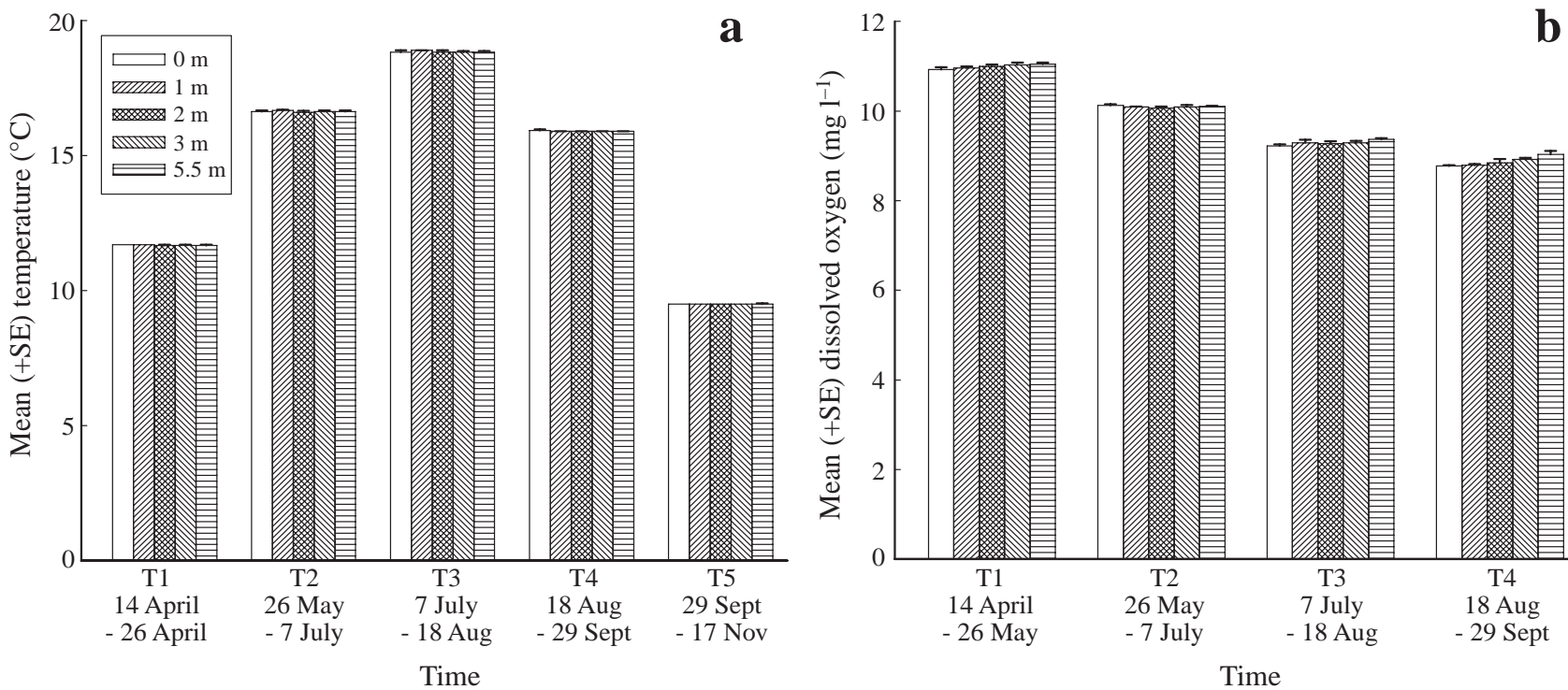

Fig. 1. (a) Temperature and (b) dissolved oxygen concentration at varying depths during the egg-laying season (T1 to T5) of Argulus foliaceus in 2003 at Site 1
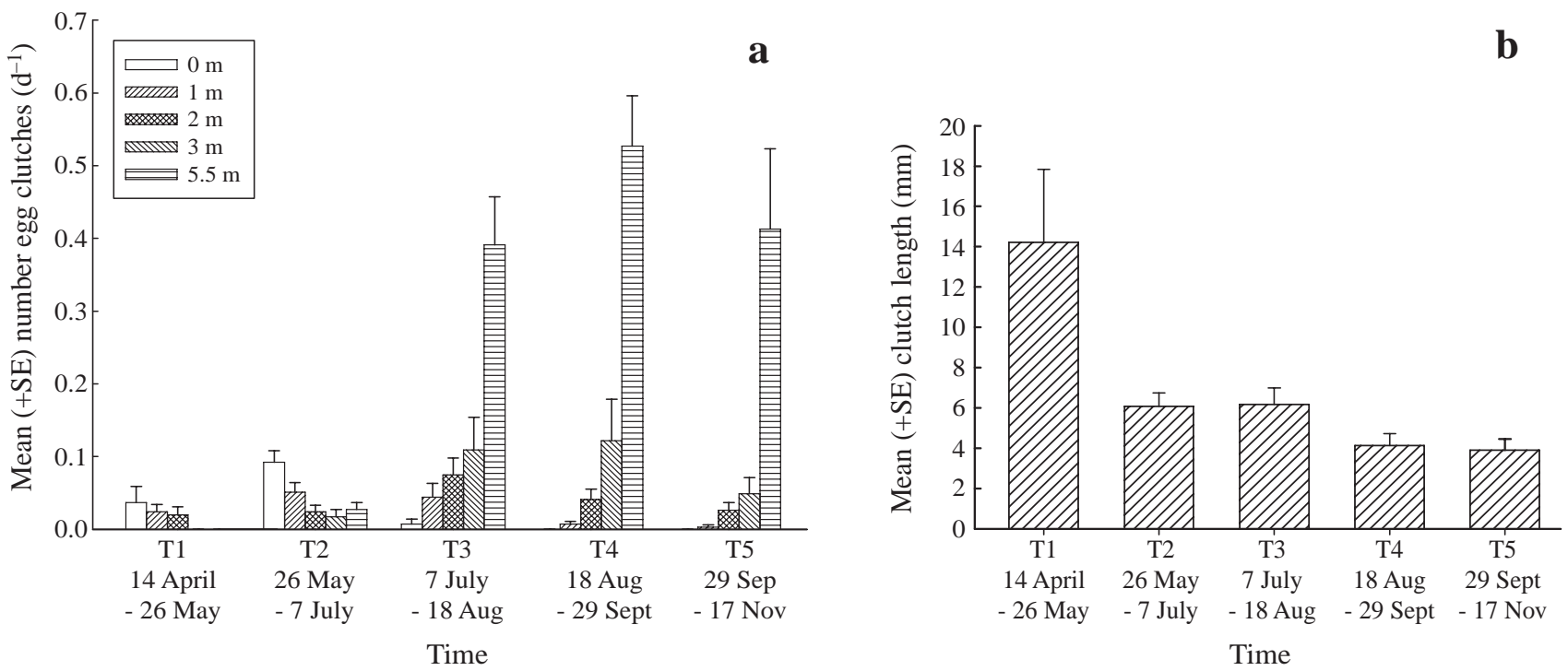

Fig. 2. Argulus foliaceus. (a) Number of egg clutches $\mathrm{d}^{-1}$ laid at varying depths and (b) clutch length during egg-laying season (T1 to T5) at Site 1 

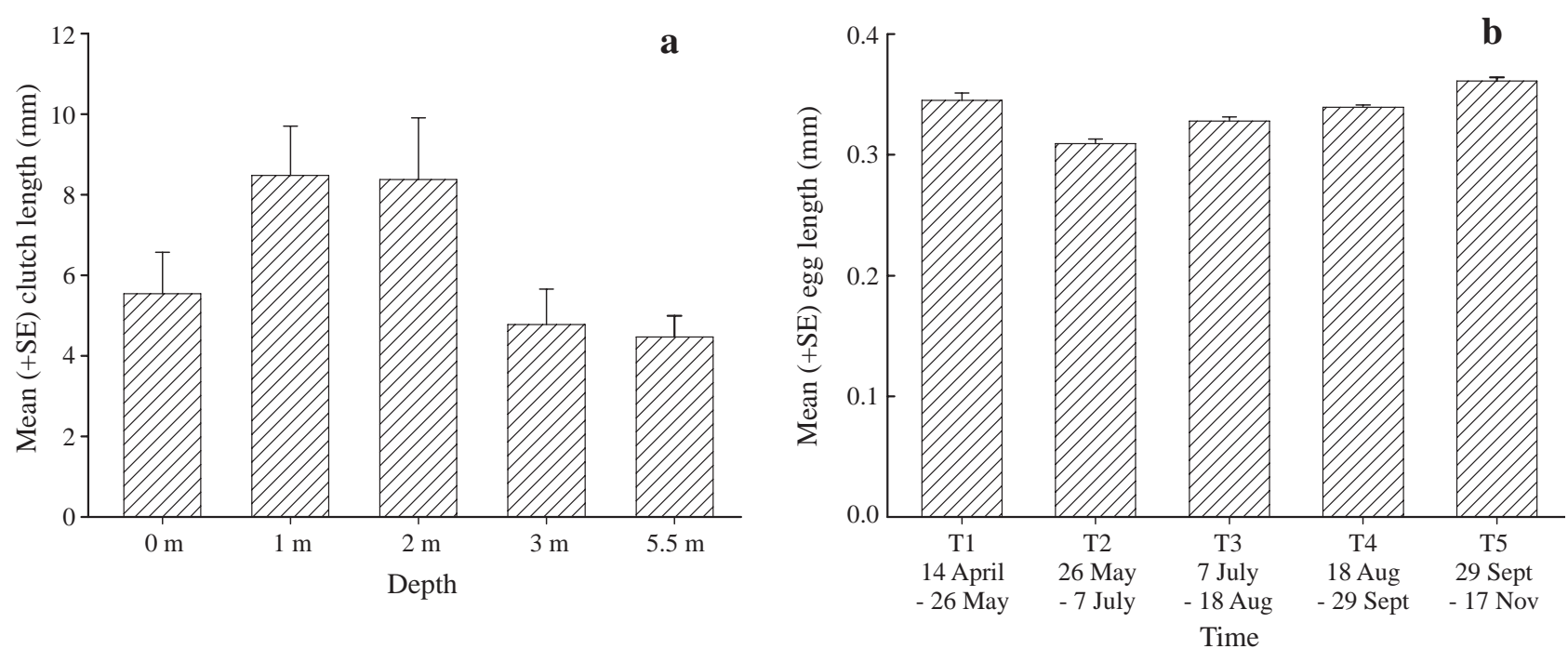

Fig. 3. Argulus foliaceus. (a) Clutch length at varying depths and (b) egg length during egg-laying season (T1 to T5) at Site 1

deep water laying. Mean clutch length was significantly different over time $\left(F_{4,91}=9.0, \mathrm{p}<0.0001\right.$; Fig. 2b), with FLSD tests showing that clutch length decreased significantly between $\mathrm{T} 1$ and $\mathrm{T} 2$ but remained similar thereafter. Mean clutch length was significantly different among depths $\left(F_{4,97}=3.2, \mathrm{p}<\right.$ 0.05; Fig. 3a), with FLSD tests showing that clutches laid at 1 and $2 \mathrm{~m}$ were significantly longer than those laid at 3 and $5.5 \mathrm{~m}$. Mean egg length was significantly different over time $\left(F_{4,91}=31.7, \mathrm{p}<0.0001\right.$; Fig. 3b), with FLSD tests showing that egg length decreased significantly between $\mathrm{T} 1$ and $\mathrm{T} 2$, increased significantly throughout $\mathrm{T} 2$ to $\mathrm{T} 4$ and reached its greatest value at T5. Mean \pm SE egg length, ranging from $0.322 \pm 0.008 \mathrm{~mm}$ to $0.337 \pm 0.005 \mathrm{~mm}$, was not significantly different among depths $\left(F_{4,91}=1.6\right)$. There was a significant positive correlation between Secchi depth and time $\left(\mathrm{r}_{26}=0.49, \mathrm{p}<0.05\right.$; Fig. 4).

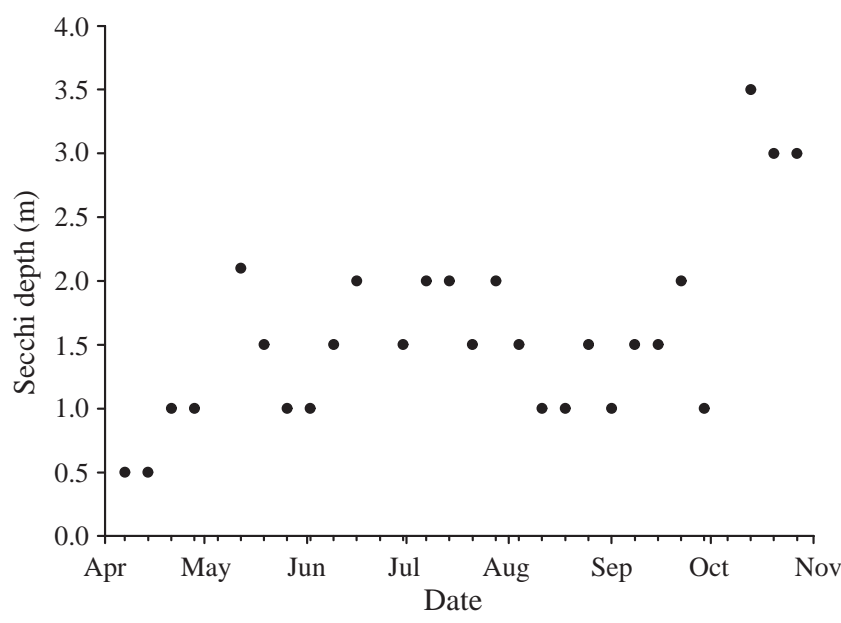

Fig. 4. Mean Secchi depth over egg-laying season of Argulus foliaceus (30 wk) at Site 1

\section{Site 2}

Egg clutches were first observed on the boards on 4 June, considerably later than at Site 1 . The water temperature at this time was $15.6^{\circ} \mathrm{C}$. Egg-laying was continuous throughout the season until 29 October, when the water temperature fell below $9^{\circ} \mathrm{C}$. Mean number of egg clutches differed significantly among depths $\left(F_{4,16}=28.1, \mathrm{p}<0.0001\right.$; Fig. 5a) and over time $\left(F_{1,16}=224.6, \mathrm{p}<0.0001\right)$, with a significant interaction effect $\left(F_{4,16}=46.1, \mathrm{p}<0.0001\right)$. Fig. 5a shows a dramatic increase in egg-laying activity at $\mathrm{T} 2$, with a shift from predominantly shallow laying to deep water laying. Mean clutch length was significantly smaller at T2 $(4.1 \pm 0.24 \mathrm{~mm})$ than at $\mathrm{T} 1(8.4 \pm 1.83 \mathrm{~mm})\left(t_{44}=2.5, \mathrm{p}<\right.$ 0.05). Mean clutch length was significantly different among depths $\left(F_{4,39}=4.3, \mathrm{p}<0.01\right.$; Fig. $\left.5 b\right)$, with FLSD tests showing a significant decrease in clutch length between 0 and $2 \mathrm{~m}$ but with length remaining similar thereafter. Mean egg length was significantly greater at T2 $(0.336 \pm 0.001 \mathrm{~mm})$ than at T1 $(0.318 \pm 0.003 \mathrm{~mm})$ $\left(t_{44}=6.0, \mathrm{p}<0.0001\right)$. Mean egg length, ranging from $0.324 \pm 0.005 \mathrm{~mm}$ to $0.332 \pm 0.002 \mathrm{~mm}$, was not significantly different among depths $\left(F_{4,39}=0.4\right)$. Water clarity was much greater than at Site 1, with the Secchi depth never falling below $2.5 \mathrm{~m}$. There was a slight positive correlation between Secchi depth and time but this was not significant $\left(\mathrm{r}_{20}=0.47, \mathrm{p}=0.08\right)$.

\section{DISCUSSION}

Seasonal patterns in egg-laying activity followed those observed by Gault et al. (2002). Our finding of a significantly larger mean egg clutch length during T1 (both lakes) was most probably the result of an over- 

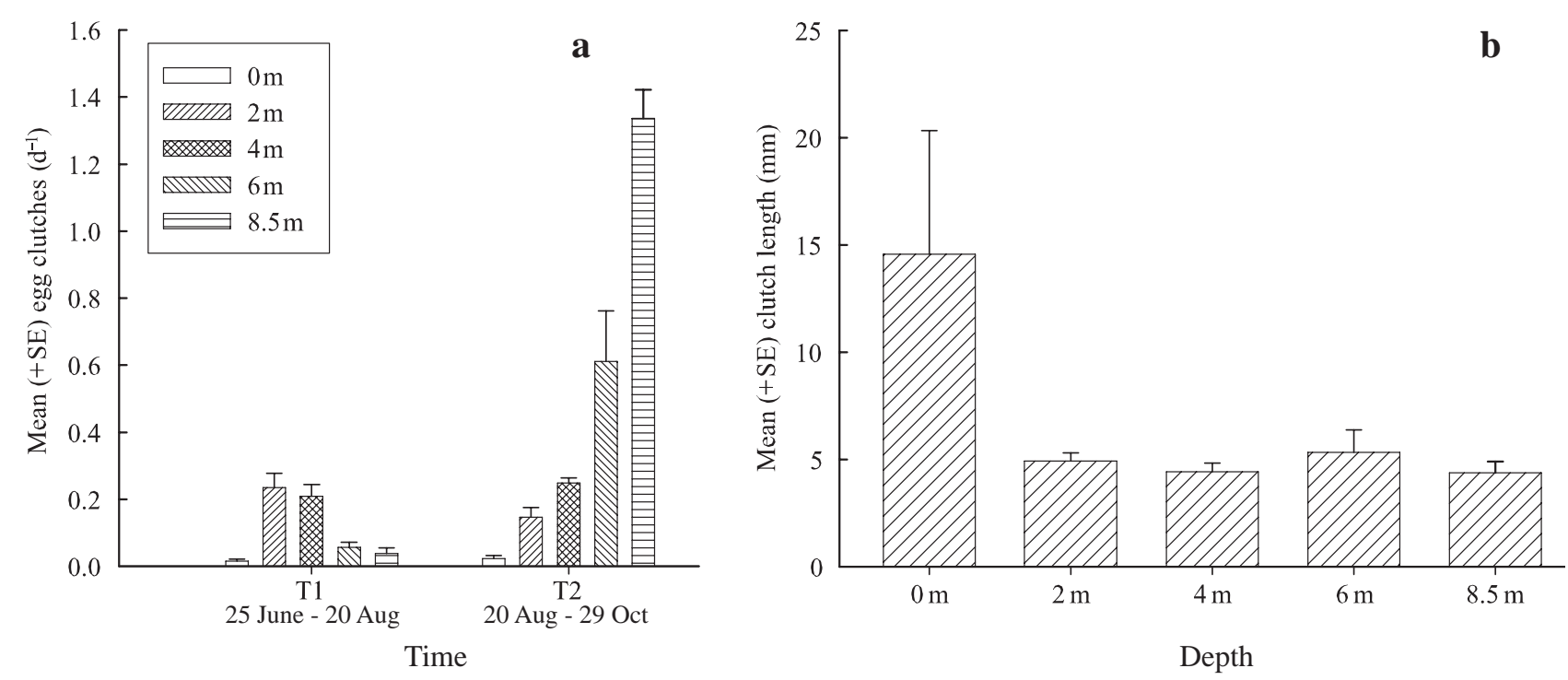

Fig. 5. Argulus foliaceus. (a) Number of egg clutches $d^{-1}$ laid at varying depths over egg-laying season (T1 to T2) and (b) clutch length at varying depths at Site 2

wintered population of large female lice that began to lay their eggs as the water temperature increased above $\sim 10^{\circ} \mathrm{C}$ (Gault et al. 2002). An initial decrease in mean egg length between T1 and T2 at Site 1 (Fig. 3b) supports this. The gradual increase in mean egg length from T2 to T5 may indicate a gradual increase in size of a new generation of females that had hatched from over-wintered eggs. Although these findings are not reflected in Site 2, this is to be expected as the egglaying season was only divided into 2 time periods at this site and thus subtle differences in mean egg length would not be evident. Furthermore, the level of infestation at Site 2 was much less than that at Site 1. Variation in mean clutch length over depth is likely to be linked to the variation in mean clutch length over time. The larger mean clutch length during T1 coincided with shallow water laying, and hence would explain the significantly larger mean clutch length in the top $2 \mathrm{~m}$.

Previous authors quote the egg-laying depth of Argulus foliaceus as being restricted to the top 1 or $2 \mathrm{~m}$ of the water column (Bauer 1959, Mikheev et al. 2001, 2003), although in some of these studies (carried out at fish farms), the maximum egg-laying depth recorded may simply be a reflection of the maximum water depth available. The present investigation, however, provides conclusive evidence of deep water egg-laying in this species, with egg clutches being preferentially laid at depths of down to $8.5 \mathrm{~m}$ during the latter half of the egg-laying season.

Water temperature may play a role in determining the vertical distribution of egg-laying throughout the season. As the major differences in water temperature were seasonal, it was thought that an increase in water temperature throughout the summer months may act as a trigger for a switch to deep water laying. However, even at the end of the egg-laying season, when the water temperature had decreased to $8^{\circ} \mathrm{C}$, egg clutches were still preferentially laid on the bottom boards. Thus, with no significant variation in temperature at any one time over the depth ranges investigated in this study, it is suggested that water temperature is not the main factor contributing to the control of egg-laying depth, although it may be one of a number of contributing factors.

Dissolved oxygen is an important factor contributing to the survival and health of freshwater fishes, with a value of $7 \mathrm{mg} \mathrm{l}^{-1}$ being regarded as the minimum concentration at which salmonids will thrive (Welch \& Lindell 1980). Salmonids tend to prefer deeper, well oxygenated water (Gardiner 1984), and it would be tempting to conclude that the higher dissolved oxygen levels at greater depths at Site 1 during the second half of the egg-laying season might have been responsible for a shift in habitat use by the host fish and hence a shift in the egg-laying depth of Argulus foliaceus. Although statistically significant, the biological significance of the variation in dissolved oxygen is debatable, with a maximum difference of only around $0.4 \mathrm{mg} \mathrm{l}^{-1}$ being found between 0 and $4 \mathrm{~m}$. A change in dissolved oxygen by this amount is unlikely to elicit a marked change in habitat utilisation by the host fish species, which can thrive in concentrations above $7 \mathrm{mg} \mathrm{l}^{-1}$, a minimum value below which dissolved oxygen concentrations never fell throughout the entire season at any depth. We cannot rule this factor out entirely, however, as small changes in the dissolved oxygen concentration at different depths may have subtle effects on 
the habitat utilisation of smaller organisms in the food web, and thus could indirectly lead to a habitat shift in the salmonid population.

Secchi depth showed marked variation throughout the egg-laying season, but with daily fluctuations in both light intensity and biotic conditions such as algal blooms, extrapolating the weekly data on water clarity to give a reliable view of seasonal trends may be dubious. Nevertheless, there is some evidence of a trend of increased Secchi depths during the latter half of the egg-laying season, which may have influenced the shift to deep water egg-laying seen at this time. Argulus foliaceus are observed to lay their eggs on the under surfaces of rocks, and in shaded areas in preference to areas exposed to direct sunlight (Bauer 1959, Gault et al. 2002). The clarity of the water, and hence the depth to which sunlight will penetrate, is likely to be a major factor influencing egg-laying depth. Adopting a technique for measuring seasonal light intensity and investigating trends in Secchi depth in more detail may be helpful in understanding the importance of this environmental factor in controlling the vertical distribution of egg-laying in this species.

Mikheev et al. (2003) suggest that Argulus foliaceus lay their eggs in shallow water habitats due to their association with their preferred host species, perch and roach, which are usually found close to the shore in boreal waters in the summer, whilst salmonids, the preferred hosts of $A$. coregoni (another European species of argulid) inhabit deeper water. Our findings, however, show $A$. foliaceus to preferentially exhibit deep water egg-laying in a large mixed fishery environment (Site 2) which contains rainbow trout, perch, rudd and pike. It is recognised that the spatial distribution of our samples (mainly in the centre of the lake) does not take into account the shallow water laying that inevitably occurs around the lake margins, which potential host juvenile percids and cyprinids are likely to inhabit. However, this does not detract from the findings that deep water egg-laying does occur in this species. Further work on host preference between salmonids, percids and cyprinids, and other host species such as sticklebacks (for example) is required to understand the influence of host choice in temperate waters and to what extent this may influence the prevalence of epizootics of this parasite.

Another possible explanation for the changes in egglaying depth throughout the season could be the effect of seasonal changes in bottom vegetation of the lake. For example, in early spring, bottom vegetation may be sparse, with a gradual increase in vegetation (and thus potential egg-laying sites) throughout the summer months. This has not been quantified in this investigation, however, and would need to be tested before any valid conclusions could be drawn.
Although more work is needed to understand the main controlling factors of egg-laying depth of Argulus foliaceus and its host selection in a mixed fishery environment, the conclusive evidence of deep water laying presented in this paper is of great interest, and gives new insight into the life cycle of this harmful and commercially important parasite species. Effective control measures using egg-laying boards need to target deep as well as shallow egg-laying if populations are to be significantly reduced. Overlooking such deep water laying behaviour would otherwise enhance the likelihood of A. foliaceus maintaining and possibly increasing its population with time. Data from this investigation, as well as future work on host choice and host location, will help us to further understand the controlling mechanisms of this critical stage in the life cycle of A. foliaceus. Such knowledge is essential for the development of appropriate and effective biological control methods for this species in stillwater fishery settings.

Acknowledgements. The authors thank Bangor Angling Club for their cooperation in this study and for the use of their facilities. We also thank S. Stewart and P. Wilson for assistance with data collection. This work was funded through a $\mathrm{PhD}$ studentship to A.J.H. from the Department for Employment and Learning.

\section{LITERATURE CITED}

Bauer ON (1959) The ecology of parasites of freshwater fish. In: Parasites of freshwater fish and the biological basis of their control. Bull St Sci Res Inst Lake River Fish 49:3-207 (Transl. from Russian: Israel Program for Scientific Translations, Jerusalem, 1962)

Bower-Shore C (1940) An investigation of the common fish louse, Argulus foliaceus (Linn.). Parasitology 32:361-371

Gardiner WR (1984) Estimating population densities of salmonids in deep water in streams. J Fish Biol 24:41-49

Gault NFS, Kilpatrick DJ, Stewart MT (2002) Biological control of the fish louse in a rainbow trout fishery. J Fish Biol 60:226-237

Hakalahti T, Pasternak AF, Valtonen ET (2004) Seasonal dynamics of egg-laying and egg-laying strategy of the ectoparasite Argulus coregoni (Crustacea: Branchiura). Parasitology 128:655-660

Hoffman GL (1977) Argulus, a branchiuran parasite of freshwater fishes. US Fish Wildl Serv Fish Dis Leafl 49

Holland CV, Kennedy CR (1997) A checklist of parasitic helminth and crustacean species recorded in freshwater fish from Ireland. Biology and Environment: Proc R Ir Acad Sec B 97:225-243

Kabata Z (1970) Diseases of fishes. Book I. Crustacea as enemies of fishes. TFH Publications, Neptune City, NJ

Mikheev VN, Pasternak AF, Valtonen ET, Lankinen Y (2001) Spatial distribution and hatching of overwintered eggs of a fish ectoparasite, Argulus coregoni (Crustacea: Branchiura). Dis Aquat Org 46:123-128

Mikheev VN, Pasternak AF, Valtonen ET (2003) How do fish ectoparasites Argulus spp. (Crustacea: Branchiura) match with their hosts at the behavioural and ecological scales? Zh Obshch Biol 64:238-247 
Northcott SJ, Lyndon AR, Campbell AD (1997) An outbreak of freshwater fish lice, Argulus foliaceus L., seriously affecting a Scottish stillwater fishery. Fish Manag Ecol 4:73-75

Pasternak AF, Mikheev VN, Valtonen ET (2000) Life history characteristics of Argulus foliaceus L. (Crustacea: Branchiura) populations in central Finland. Ann Zool Fenn 37:25-35

Rahman M (1995) Some aspects of the biology of a freshwater

Editorial responsibility: Jay F. Levine, Raleigh, North Carolina, USA fish parasite, Argulus foliaceus (L.) (Argulidae. Branchiura, Crustacea). Bangladesh J Zool 23:77-86

Sokal RR, Rohlf F (1995) Biometry. The principles and practice of statistics in biological research, 3rd edn. WH Freeman \& Co, New York

Welch EB, Lindell T (1980) Ecological effects of wastewater. Applied limnology and pollutant effects. E \& FN Spon, London

Submitted: October 4, 2004; Accepted: October 5, 2005

Proofs received from author(s): January 25, 2006 